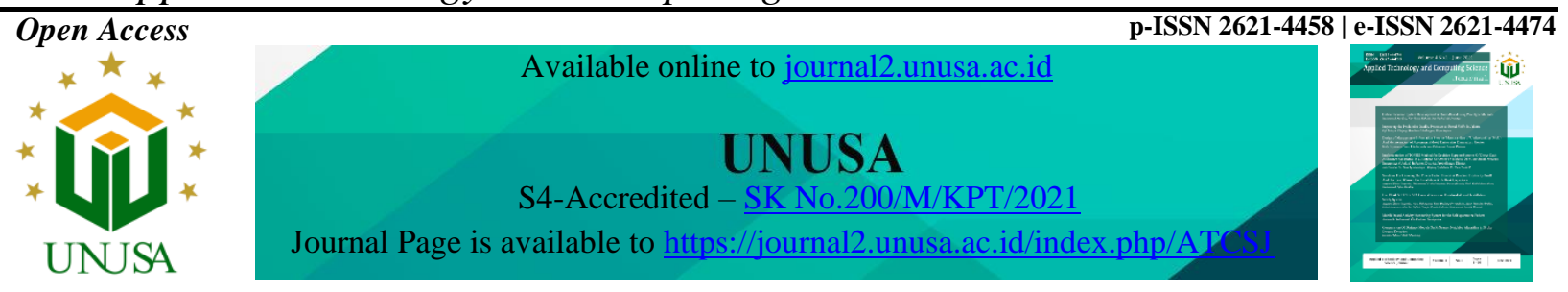

\title{
Improving the Production Quality Processes at Bread SMEs in Jakarta
}

\author{
Fuji Rahayu Wilujeng1, Desribeth Palullungan², Tasya Regina ${ }^{3}$ \\ 1,2,3 Universitas Bunda Mulia, Indonesia \\ Jalan Lodan Raya No 2, Ancol, Jakarta Utara \\ 1*fwilujeng@ bundamulia.ac.id, ${ }^{2}$ dpalullungan@bundamulia.ac.id
}

\section{Article history:}

Received 6 May 2021

Revised 30 June 2021

Accepted 14 July 2021

Available online 31 July 2021

Keywords:

Bread SMEs

Control Chart

Prototype

Kaizen

Quality

\begin{abstract}
The consumption pattern of the people in Indonesia is experiencing a shift. Consumption patterns that are influenced by socio-cultural factors today make people tend to consume food and drinks that are practical and easy to obtain. This pattern began in 2014 until now, making the percentage of food consumption increase by $2.5 \%$ per year. Bread is a finished food whose demand pattern has also increased. Due to the development of the middle-class population, an increase in the income of young people, and society's consumption pattern, which is increasingly shifting to a practical urban consumption pattern. The bread industry in Indonesia is still classified as the small and medium enterprises (SME) sector. Small and medium enterprises (SME) is a business sector with a significant impact on improving the economy in developing countries. The products are distributed to offices that work with bakeries and are sold in stores. This shows that the shop production must work quickly to meet consumer demand in the surrounding area. In fulfilling consumer demand, a production quality control process is required in the workstation to reduce defective products. This study aims to carry out a quality control process to reduce faulty products by using a control chart and the concept of kaizen to control and maintain the production process in bread SMEs so that quality and work effectiveness can be realized.
\end{abstract}

\section{INTRODUCTION}

The consumption pattern of the people in Indonesia is experiencing a shift. Consumption patterns that are influenced by socio-cultural factors today make people tend to consume food and drinks that are practical and easy to obtain. This has been going on since 2014, when consumption of processed food has continued to increase by $2.5 \%$ annually [1]. Until 2018 , BPS recorded data on consumption per capita for food and beverages, so it reached the highest consumption compared to consumption of other types of food, which was IDR 202,150 per capita [2].

Bread is one of the profitable finished food products. The bakery industry in Indonesia is experiencing an increase of $15 \%$ in line with the demand from consumers [3]. The growing bread industry is triggered by

\footnotetext{
1* Corresponding author
} 
the middle-class population growth, an increase in the income of young people, and consumption patterns that are increasingly shifting to practical urban consumption [3]. This makes the demand for bread increase and potentially to be a profitable business.

The bread industry in Indonesia has included the small and medium enterprises (SME) sector. SMEs are a business sector that has a significant impact on improving the economy in developing countries. The contribution of SMEs in improving the economy through labor absorption. In 2018, SMEs managed to absorb $97.22 \%$ of the workforce [4].

Even the contribution of SMEs in Indonesia has had a significant impact on economic growth. However, SMEs still need improvements in work efficiency and effectiveness. It is intended so that SMEs can quickly meet consumer demand, contributing to improving the welfare of SMEs in Indonesia. Bread SMEs in Taman Galaxy, Bekasi Selatan is an SMEs that was founded in 2009. The products are distributed to offices that work with bakeries and are sold in shops. It shows that the shop production must work quickly to meet consumer demand in the surrounding area.

In fulfilling consumer demand, a quality production process is needed to reduce defective products. Production control to improve the quality and effectiveness of work can be done by various methods, such as a Control Chart and Concept of Kaizen. A control chart is a method for controlling product quality. In addition, the concept of kaizen aims to increase human productivity [5]. The implementation of kaizen in the 5S (Seiri, Seiton, Seiso, Seiketsu, dan Shitsuke) concept has been proven to maintain and increase the quality of the production process. Therefore, the control chart and kaizen concept are expected to be a solution in controlling and maintaining the production process in bread SMEs so that work quality and effectiveness can be realized.

\section{RELATED WORKS}

This study uses two frameworks, the Concept of Quality Control and Kaizen, which can solve production problems and maintain sustainable production processes. A control chart is a measurement that is adapted to the control process between predetermined boundaries. The leading cause of variabilities must be eliminated [6]. The control chart is a graph that monitors an ongoing process. Three lines are shown on the control chart, namely the centerline, which usually represents the average value of the plotted characteristics showing where the process is centered. The upper control limit and the lower control limit are used to decide the process [7]. The control chart is divided into two types, namely the variable control chart and the attribute control chart.

Kaizen is a term in Japanese which means continuous improvement or improvement involving all aspects [8]. This method aims to make continuous improvements in quality, process, corporate culture, technology, productivity, security, and leadership [9]. The 5S methodology is one of the methods in kaizen that aims to improve quality, safety and provide efficient and effective performance. The focus of this method is to simplify the work environment and minimize waste [10] They are Seiri (sort), Seiton (simplify), Seiso (shine), Seiketsu (standardize) and Shitsuke (sustain). Seiri (Sort) means arranging everything according to specific rules and principles by distinguishing or separating between what is needed and what is not needed. Seiton (Simplify) means storing items in the right place according to the proper layout. The primary purpose of simplifying is to eliminate the activity of searching. Seiso (Shine) means clean everything from trash and dirt. Seiketsu (Standardize), the refinement of the next three stages by standardizing it with continuous improvement or maintenance. Shitsuke (Sustain) means providing training and skills for workers to have a strong desire to do a job even though the job is difficult [5].

\section{METHODS}

The data collection stage is carried out by direct observation and interviews with employees who work at the SMES bakery to find out data related to research such as the amount of production each day, the number of defects each day, how to market, and the supplier of raw materials.

Data analysis was performed by calculating the DPMO of the product, the Six Sigma value of bread 
production to determine the sigma level of the product, and calculating the control chart using the p-chart. The improvement and control stage is carried out using the kaizen method to analyze the factors that cause defects so that quality improvements can be made.

At the conclusion and suggestion stage, it contains conclusions from the research that has been done and provides suggestions for future research.

\section{RESUlTS AND Discussions}

The data collection stage was carried out by conducting observations and direct interviews with the small bread-making SME home businesses in Jakarta. Every day, these SMEs make Bread with a total production of about 200 loaves. At the same time, the number of samples taken is constant as many as 50 samples.

The define stage begins by determining and defining a description of the CTQ (Critical To Quality) relating to quality standards and quality dimensions that must be maintained. Three causes of defects in tempeh, namely the Bread does not expand completely due to an error in the composition of the dough, the inside of the Bread is hard, the level of contamination by mold, dust, and other foreign objects. These three defects are the most common and can be defined as Bread does not expand completely, and level of contamination by mold, dust, and other foreign matter.

Bread does not expand perfectly can be caused by the composition of the dough is not right. This is mostly caused by human or employee error to determine the composition of the dough. The inside of the Bread is hard because it has something to do with the wrong composition of the dough or the oven is too long. The level of contamination by mold, dust, and other foreign matter caused by the fermentation process or the storage of Bread is not good, and the production room is not clean enough. Besides that, it can be caused by humid room temperature and human error.

At this measure or measurement stage, the DPMO (Defect per Million Opportunities) calculation is carried out to determine the sigma level and the calculation of the $\mathrm{p}$ control map with constant samples to find out the UCL (Upper Control Limit) and LCL (Lower Control Limit). Here are the results of the calculations:

Defect per Unit

$$
\begin{aligned}
\text { DPU } & =\text { Defect }(\mathrm{D}) \div \text { Unit Produced }(\mathrm{U}) \\
& =210 \div 4000 \\
& =0,0525
\end{aligned}
$$

$$
\begin{aligned}
& \text { Total Oppurtinities } \\
& \text { TOP }=\mathrm{U} \times \mathrm{OP} \\
& =4000 \times 3 \\
& =12000 \\
& \text { Deffect per Oppurtinities } \\
& \text { DPO }=\mathrm{D} \div \mathrm{TOP} \\
& =210 \div 12000 \\
& =0,0175 \\
& \text { Deffect per Million Oppurtinities } \\
& \text { DPMO }=\mathrm{DPO} \times 1000000 \\
& =0,0175 \times 1000000 \\
& =17500
\end{aligned}
$$

Based on the DPMO value, the sigma value is 3.61. After doing the DPMO calculation, it is continued by making a control chart, as shown in Figure 1. 


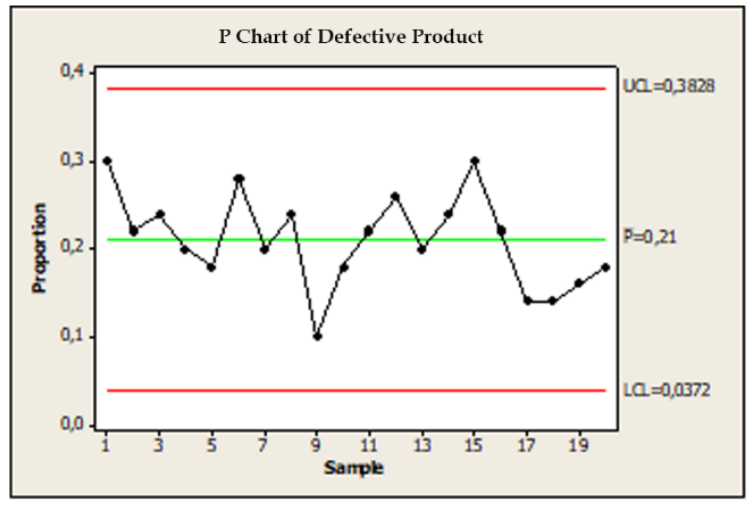

Figure 1. Control Chart $\mathrm{P}$

Figure 1 shows that there are no products out of control, then the production process can still be said to be good and is still in a controlled process but still needs to be controlled.

Our analysis will be carried out regarding the most dominant defects in the bread-making process. The Pareto diagram in Figure 2 shows us the percentage of each defect that has the most dominant percentage. This diagram shows the problem based on the number of events.

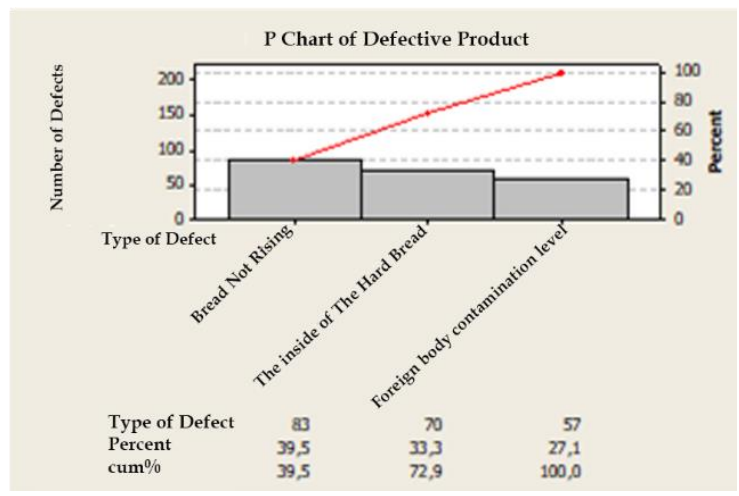

Figure 2. Pareto Chart

The Pareto diagram in Figure 2 shows the type of bread that does not expand ideally has a percentage of $39.5 \%$, then the type of defect The inside of the bread is hard with a percentage of $33.3 \%$ and the type of defect The level of contamination by mold, dust and other foreign objects is $27,1 \%$. In the Pareto diagram, it can be seen that the most dominant defect is a defect of the type of bread that does not expand perfectly, so the focus is on quality control of this defect.

After analyzing the defect problem in the bread-making process, the Kaizen method is then repaired and controlled. The method taken from kaizen is a method that aims to improve quality and safety and can provide efficient and effective performance.

The implementation of Seiri is carried out by sorting the bread-making equipment according to its function and the flow of the bread-making process so that it is easier to find if you want to use it. Sorting bread-making equipment based on the level of importance from the most frequently used equipment to those that are rarely used so that it is more compact and not scattered. Throw away damaged and unused utensils such as rusty bread pans, and other utensils that have not been used for a long time.

The implementation of Seiton the section is carried out such as rearrange the bread-making utensils on the storage rack, so they are neatly organized. Place the bread-making utensils that have been used back onto the storage rack. Conduct grouping on bread raw materials and naming bread raw materials that are still in use. So that they are easy to find, and make instructions for using the composition and dosage of 
bread dough and the process of making it in detail and then place it on the bread dough holder to minimize bread defects from expanding completely due to an incorrect measurement of bread dough.

Implementation of seiso is done by performing cleaning in all areas of production and storage of bread making. Determine a regular cleaning schedule for bread production places, especially on bread storage racks and coolers, to reduce bread defects due to mold contamination, dust, and other foreign objects. Determine a good location to dispose of the remaining production waste so as not to interfere with employee productivity.

The implementation of Seiketsu is done by added storage facilities for bread production equipment additional facilities for trash bins or trash carts. Checking bread dough machines and ovens periodically so that the oven humidity and temperature (calibration) in the oven are maintained according to standardization even though the oven is repeatedly used to reduce internal defects of hard bread. The addition of safety devices in the production process such as rags, aprons, and baking trays from a hot oven. Making storage racks and cooling bread temporarily before the bread is packed closed to minimize the bread on the shelf is contaminated with foreign objects.

The implementation of Shinsuke is done by implement strict rules so that employees are more disciplined. When entering the bakery production area, all employees should be required to wear aprons and hair covers, and plastic gloves to minimize bread defects contaminated by foreign objects due to hair. More regular supervision of all employees. Conduct cake-making training for new employees, especially those who are not experienced. Wash your hands regularly before starting the bread-making process and wear plastic gloves to keep the bread hygienic.

\section{CONCLUSIONS AND RECOMMENDATIONS}

The results of this study recommend the application of Kaizen in the bakery SMEs in order to improve the quality of SMEs in terms of management to bread production. In addition, SMEs must focus on improving the three main factors that cause failure in bread production. It is hoped that after SMEs have implemented Kaizen principles, the quality improvement of all production lines.

Based on the analysis and discussion that has been carried out, the suggestions that can be given are as follows:

1. Implementing of recommendations for improvement based on the Kaizen $5 \mathrm{~S}$ analysis method (seiri, seiso, seiton, seiketsu, and shitsuke).

2. Making a quality report or notes regarding the amount of production, the number of product defects, and problems that cause defects in the production process regularly.

3. Employees should strictly control and paying attention to the procedure for making bread dough, especially in the process of mixing the dough composition.

4. Providing training for employees regularly so that a comparison can be made of whether it has increased from the previous production process.

5. Supervising any repairs that will be made.

\section{REFERENCES}

[1] S. K. Rizka, Y. L. Purnamadewi, and N. Hasanah, "Produk Roti dalam Pola Konsumsi Pangan dan Keberadaan Label Halal dalam Keputusan Konsumsi Masyarakat ( Kasus : Kota Bogor )," J. AlMuzara'ah, vol. 6, no. 1, pp. 15-27, 2018, doi: 10.29244/jam.6.1.15-27.

[2] M. I. Khoer, Pegeluaran Untuk Konsumsi Penduduk Indonesia Per Provinsi 2018, 3rd ed., no. September. Jakarta: BPS-Statistic Indonesia, 2018.

[3] L. Nurhidayah, "Industri Roti Tumbuh Hingga 15 Persen Per Tahun," Wartaekonomi.co.id, 2016. .

[4] Kompas, "Kontribusi UMKM," Kementerian Perindustrian Republik Indonesia, 2018. .

[5] R. Soesilo, "Implementasi Kaizen dan 5S Pada Pengeringan Produk Di Proses Plating," J. Tek. Ind., vol. 18, no. 2, pp. 121-126, 2017.

[6] E. L. Cano, J. M. Moguerza, and M. P. Corcoba, Quality Control with R An ISO Standards Approach. Switzerland: Springer, 2015. 
[7] A. Mitra, Fundamentals of Quality Control and Improvement, Fourth Edi. Canada: Wiley, 2016.

[8] R. Andiwibowo, J. Susetyo, and P. Wisnubroto, "Pengendalian Kualitas Produk Kayu Lapis Menggunakan Metode Six Sigma dan Kaizen Serta Statistical Quality Control Sebagai Usaha Mengurangi Produk Cacat," J. REKAVASI, vol. 6, no. 2, pp. 60-118, 2018.

[9] M. Imai, Kaizen: Kunci Sukses Jepang Dalam Persaingan. Jakarta: PT Pustaka Binaman Presindo, 2001.

[10] M. Kabir, S. Boby, and M. Lutfi, "Productivity Improvement by Using Six Sigma," Int. J. Eng. Technol., vol. 3, no. 12, pp. 56-84, 2013. 